\title{
Implemementasi Website Alumni Pada SMP PGRI 1 Padang
}

\author{
Yanti Yusman*a , Salman Paris Harahapb \\ Universitas Pembangunan Pancabudi, Fakultas Sistem Komputer a \\ Universitas Pembangunan Pancabudi, Fakultas Sosial Sains ${ }^{b}$ \\ yantiyusman@dosen.pancabudi.ac.id
}

\begin{abstract}
Abstrak
Alumni merupaka aset penting yang harus dirangkul dan dikembangkan sedini mungkin. Sehingga upaya peningkatan mutu tidak bisa dibebankan sepenuhnya pada sekolah, namun kerjasama dan sinergi yang harmonis antara alumni dengan sekolah, dan orang tua siswa akan memiliki dampak yang besar bagi pengembangan sekolah secara berkesinambungan dimasa yang akan datang. Sehingga SMP PGRI 1 PADANG merancang suat sistem informasi berbasis website untuk mengelola data alumni dengan alat bantu uml (Unified Modeling Language ) untuk memindahkan konsep sistem yang dirancang ke dalam bentuk program. Adapun program yang dibuat mengunakan database MySQL yang dapat menampung jumlah data alumni yang setiap tahun semakin bertambah. Dan akan dikoordinir secara baik sehingga tidak akan ada tumpukan buku alumni dan memudahkan pekerjaan dalam melakukan pencarian data alumni sehingga membuat perkerjaan lebih efisiien.
\end{abstract}

Keywords: Website, Alumni,UML,DataBase.

\section{Pendahuluan}

Perkembangan IPTEK (Ilmu Pengetahuan dan Teknologi) cenderung dikaitkan dengan komputer yang sangat penting penggunaannya dan bertujuan untuk mempermudah manusia dalam pekerjaan dalam menghasilkan informasi. Informasi adalah data yang telah dikelola dan diproses untuk memberika arti dan memperbaiki proses pengambilan keputusan (Romney dan Steinbart, 2015). Kehadiran teknologi komputer dimana internet sangat berperan penting yang menembus batasan jarak dan waktu. Kita dapat berkomunikasi dan dimana saja di seluruh dunia ini dengan fasilitas e-mail maupun dengan cara chatting. Begitu juga dalam hal menemukan suatu informasi peranan suatu website sangat penting.

Website merupakan kumpulan halaman yang menampilkan informasi data teks, data gambar, data animasi, suara, video dan gabungan dari semuanya, baik yang bersifat statis maupun dinamis yang membentuk satu rangkaian bangunan yang saling terkait, dimana masing-masing dihubungkan dengan jaringan-jaringan halaman (Hariyanto, 2015). Pentingnya peranan website dalam dunia internet membuat Para alumni bisa berkomunikasi serta bisa mengetahui perkembangan sekolah dan juga menjalin silaturahmi sesama alumn. khususnya di SMP PGRI 1 Padamg Berdasarkan uraian diatas maka dapat diambil kesimpulan bahwa Implemetasi Website Alumni ini sangat berperan didalam membantu pihak sekolah didalam mengarsipkan data alumni. Pembuatan website ini diolah dengan menggunakan Bahasa Pemrograman PHP serta database MySQL. MySQL (My Structured Query Language) adalah suatu sistem basis data relation atau Relational Database Managemnt System (RDBMS) yang mampu bekerja secara cepat dan mudah digunakan (Nugroho, 2011).

SMP PGRI 1 PADANG merupakan sekolah menengah Pertama Untuk menganalisis dalam membangun suatu website sederhana contohnya website 
Alumni Karena setelah ditelusuri oleh para alumni. Dalam berbagai kesempatan peranan alumni dalam memajukan kwalitas suatu institusi sering terlupakan pada hal alumni merupkan aset penting yang harus dirangkul dan dikemambangkan sedini mungkin. Sehingga upaya peningkatan mutu tidak bisa dibebankan sepenuhnya pada sekolah membangun suatu website dari awal. contohnya website Alumni Dalam hal ini Implemetasi ini bertujuan untuk mempermudah pihak sekolah dalam menyajikan informasi tentang alumni secara cepat dan akurat di SMP PGRI 1 Padang dalam pembuatan suatu project sederhana dalam membangun website Alumni menggunakan PHP dan MY-SQL.

\section{Metode}

Penelitian ini merupakan pendekatan yang digunakan dalam pengabdian masyarakat meliputi metode tatap muka yang digunakan dalam penyampaian materi pelatihan dengan bertemu dan bertatap muka secara langsung dan berada di tempat yang sama.metode tatap muka ini mendapatkan hasil lebih baik dengan implementasi yang diberikan kepada pihak sekolah SMP PGRI 1 Padang.

\section{Hasil dan Pembahasan}

Setelah Proses pengolahan data dilakukan analisa terhadap data para alumni di SMP PGRI 1 Padang. dilakuan implementasi pada website yang telah di disain sesuai dengan kebutuhan sekolah sehingga memberikan kemudahan dan kenyaman didalam pencatan serta mengetahui informasi alumni sehingga memberikan efek yang sangat bagus bagi pihak sekolah.

Adapun tanggapan dari pihak sekolah tentang implmentasi website alumni berbasis PHP di SMP PGRI 1 Padang mendapat respon yang sangat baik, karena dapat memberikan pengetahuan yang lebih baik kepada pihak sekolah. Operator sekolah sangat antusias dalam mengikuti implementasi website hinga akhir karena dapat mempraktekan langsung bagaimana mengunakan suatu website yang mana dalam hal ini dicontohkan dalam menjalankan website alumni SMP PGRI 1 Padang.

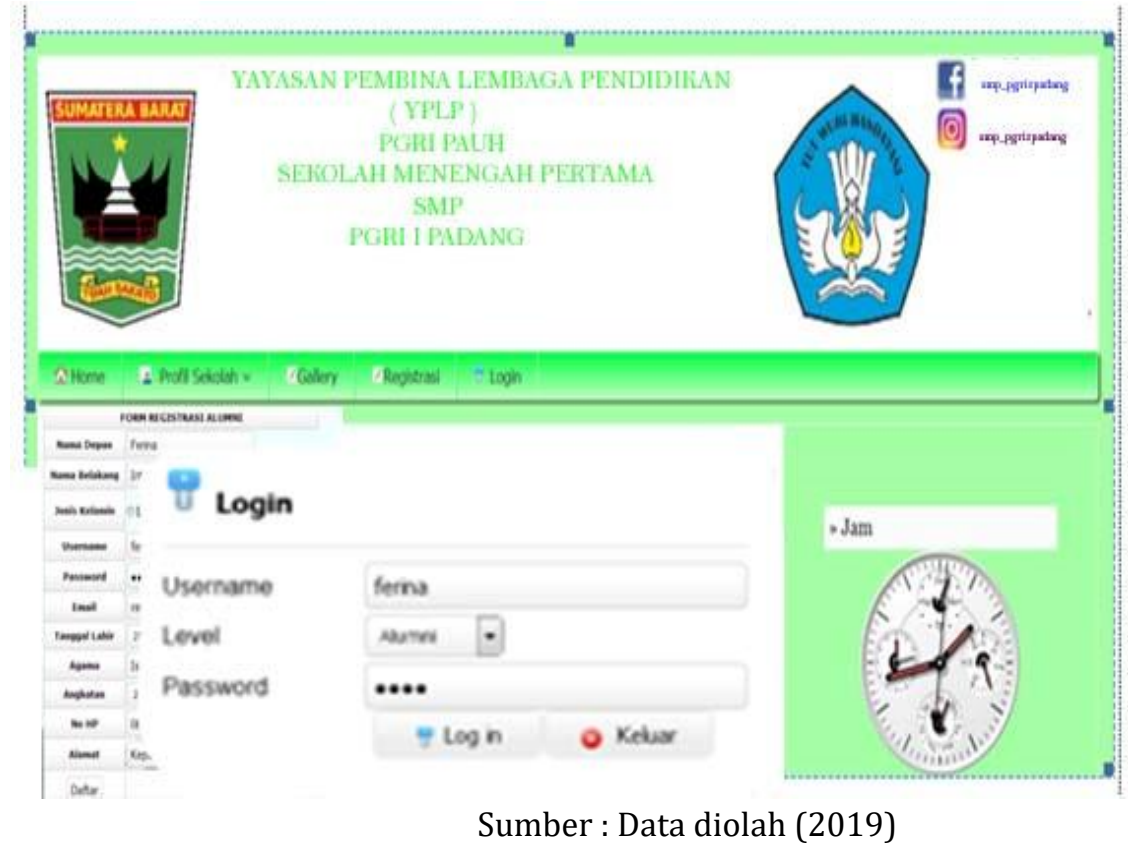




\section{Gambar 1. Tampilan login}

Respon perserta setalah pelatihan terlihat sangat memuskan, karena hasil dari tujuan yang ingin dicapai dari pengabdian ini telah berhasil dilaksanakan pada SMP PGRI 1 Padang. Operator sekolah sangat tertarik dalam mengunakan serta pemanfaatan sebuah website yang dicontohkan website alumni SMP PGRI 1 Padang.

\section{Simpulan}

Dengan adanya implementasi website alumni berbasis PHP di SMP PGRI 1 Padang. Para perserta yaitu operator SMP PGRI 1 Padang mengikuti implementasi website alumni dengan lancar, para peserta operator SMP PGRI 1 Padang mengikuti implementasi pembelajaran pengunaan website alumni berbasis PHP sangat antusias dengan implemtasi ini, karena dapat menambah pengetahuan dan melatih skill mereka dalam bidang pemogrman berbasis web.

\section{Ucapan Terimakasih}

Terima kasih kepada Lembaga Penelitian dan Pengabdian Universitas Pembangunan Panca Budi yang telah memberikan dukungan dan pendanaan skema pengabdian kepada masyarakat.

\section{Daftar Pustaka}

Hariyanto, A. 2015. Membuat Aplikasi Computer Based Test dengan PHP MySQL dan Bootstrap. Penerbit Andi. Yogyakarta.

Nugroho, A. 2011. Perancangan dan Implementasi Sistem Basis Data. Penerbit Andi. Yogyakarta.

Romney, M. B., P. J. Steinbert. 2015. Accounting Information Systems. Salemba Empat. Jakarta. 